Article

\title{
Politicization 'Reversed': EU Free Trade Negotiations with West Africa and the Caribbean
}

\author{
Anke Moerland ${ }^{1, *}$ and Clara Weinhardt ${ }^{2}$ \\ ${ }^{1}$ Department of International and European Law, Maastricht University, 6211LH Maastricht, The Netherlands; \\ E-Mail: anke.moerland@maastrichtuniversity.nl \\ 2 Department of Political Science, Maastricht University, 6211SZ Maastricht, The Netherlands; \\ E-Mail: clara.weinhardt@maastrichtuniversity.nl \\ * Corresponding author
}

Submitted: 30 November 2019 | Accepted: 17 February 2020 | Published: 31 March 2020

\begin{abstract}
The politicization of recent European Union (EU) trade negotiations such as the Transatlantic Trade and Investment Partnership or the Comprehensive and Economic Trade Agreement suggests that the more negotiations focus on deep integration issues, the higher the potential for polarization of values and interests. Yet, as we argue, this pattern does not necessarily hold true in EU trade negotiations with the developing world. In the case of the Economic Partnership Agreements with West Africa and the Caribbean region, the pattern of politicization was 'reversed': Politicization remained low in the Caribbean region, despite the inclusion of deep integration issues. To the contrary, negotiations became highly politicised in West Africa, where negotiations focussed on the traditional realm of trade in goods. Combining the insights from the literature on the role of non-state actors (NSAs) in trade policy-making in developing countries and on politicization, we show that limited pre-existing mobilisation resources of NSAs, and few opportunities to engage with the political level of negotiations, imply that those affected by the inclusion of deep integration issues hardly mobilise. We also find that lack of technical expertise and the significance of traditional trade areas pre-empts NSAs from engaging in emotive framing on deep integration issues. This helps us to unpack the different patterns of politicization across both regions: Politicization in West Africa was facilitated by civil society actors who-in contrast to the Caribbean region-could draw on pre-existing networks, expertise, and direct access to the regional negotiation level.
\end{abstract}

\section{Keywords}

deep integration; European Union; EU trade policy; Free Trade Agreement; non-state actors; politicization; trade negotiations; West Africa

\section{Issue}

This article is part of the issue "Politicization of EU Trade Policy across Time and Space" edited by Dirk De Bièvre (University of Antwerp, Belgium), Oriol Costa (Universitat Autònoma de Barcelona, Spain/IBEI, Spain), Leif Johan Eliasson (East Stroudsburg University, USA) and Patricia Garcia-Duran (University of Barcelona, Spain).

(C) 2020 by the authors; licensee Cogitatio (Lisbon, Portugal). This article is licensed under a Creative Commons Attribution 4.0 International License (CC BY).

\section{Introduction}

In the recent decade, we have witnessed increasing politicization of trade policy on a global scale. The negotiations of so-called mega-regional Free Trade Agreements (FTAs) between the European Union (EU) and both the United States and Canada respectively were particularly contested and became highly politicised. Scholars re- fer to politicization where the views of an expanding number of actors become publicly salient and polarized (De Bruycker, 2017, p. 605; de Wilde \& Lord, 2016). Much of the existing research thereon has suggested that the focus on deep integration in mega-regionals has been a driving force of higher levels of contestation. The more trade liberalization is about deep regulatory issues such as public procurement or health standards, the more 
non-state actors (NSAs) presumably get involved in public debates to push for (and protect) their own interests (Eliasson \& García-Duran, 2017). Yet, we argue that while this pattern may hold true for recent trade negotiations between high-income countries, a different picture emerges if we look at free trade negotiations that involve the EU and the developing world. We argue that financial and human capacity constraints as well as limited political and discursive opportunity structures may severely undermine the ability of NSAs to engage with the negotiation of deep integration issues.

By focussing on politicization dynamics in developing partner countries and the relationship with deep integration issues, we integrate the existing literature on politicization of EU trade policies in Europe with the literature on the role of NSAs in trade policy-making in the developing world. We thereby provide new insights on the external dimension of politicization of EU trade agreements: where the EU's deep integration negotiating agenda affects politicization in its developing partner countries, this may delay or undermine the realisation of the EU's global trade agenda.

Empirically, we examine North-South trade negotiations in the framework of the Economic Partnership Agreements (EPAs) between the EU and six regions among the African, Caribbean, and Pacific (ACP) countries-with a focus on EU-West Africa (2002-2014) and EU-Caribbean (2002-2007) negotiations. With the launch of the 'Global Europe' strategy in 2006 (European Commission, 2006), the EPAs became the first test case for the EU's new model agreement, which now contains deep integration areas such as intellectual property (IP) protection. In the EU, politicization was rather low despite the inclusion of deep integration issues in the EPAs (cf. del Felice, 2014) - arguably due to the limited economic importance of ACP countries. In contrast, the EPAs became the subject of politicization in many (but not all) of its partner countries, which are economically dependent on the EU. To understand these divergent patterns of politicization in the EU's partner countries and to explore their link to deep integration issues, this article focusses on two regions with seemingly 'reversed' politicization patterns: Politicization remained low in the Caribbean region, despite the inclusion of deep integration issues, while negotiations became highly politicised in West Africa, although the final agreement focussed on the traditional realm of trade in goods.

Regarding the different patterns of politicization, we find that in the Caribbean region, technical capacity constraints and limited participatory channels reduced the ability of NSAs to engage in politicization of deep trade issues, even if their inclusion meant that the interests of a broad range of domestic constituents were at stake. In West Africa, higher levels of politicization were driven by a group of civil society actors that were able to draw on pre-existing networks and expertise and held more direct access to the regional negotiation level. In neither case, however, did the inclusion of deep integration issues fa- cilitate mobilisation of a broader range of NSAs, or 'emotive' framings that resonate broadly.

On a conceptual level, our findings thus question the presumed link between politicization of EU trade policies and the greater depth of regulatory commitments that the EU's FTAs recently included (De Bièvre \& Poletti, 2020, see therein Young \& Peterson, 2006; Eliasson \& García-Duran, 2017; Laursen \& Roederer-Rynning, 2017; Young, 2017). This is in line with existing research that emphasises the importance of intermediary variables that may undermine politicization. In this regard, we uncover how the particular hurdles that NSAs may face in developing country contexts interacted with mobilisation resources, political opportunity structures, and discourse opportunity structures that shape patterns of politicization. Moreover, our findings indicate more generally that if the EU negotiates deep integration issues with developing country partners, the level of awareness among NSAs will vary greatly and will oftentimes be low. This means, firstly, that support or opposition to including deep integration issues may primarily depend on the political preferences of state representatives, rather than the positions of NSAs. Secondly, if NSAs engage in politicization, they are less likely to focus the limited resources they have on complex deep integration issues, even if they are knowledgeable about them.

In the following, we briefly review the existing literature on the politicization of (EU) trade policies and present our conceptual and methodological approach. We then discuss the findings regarding politicization in developing countries from our two case studies on the Caribbean region and the West African region in the EPA negotiations with the EU. Note that the Caribbean case study focusses in particular on the negotiations of the 'Innovation and Intellectual Property' chapter of the Caribbean Forum (CARIFORUM)-EC EPA as one of the most prominent areas of deep integration issues. The West African case examines trade in goods and deep integration issues, given that the latter were ultimately excluded from the agreement. Note that both case studies focus on politicization through political activities of NSAs, rather than an examination of media discourse (cf. Gheyle, 2016). For our analysis, we rely on press releases, publications, and qualitative data, which we complement with evidence from 30 interviews conducted between 2008 and 2012 with policy-makers, negotiators, and NSAs from both regions, as well as with EU officials involved in EPA negotiations.

\section{The Politicization of Trade Policies: Deep Integration versus Traditional Trade Issues}

Politicization is generally referred to as an "increase in polarization of opinions, interests or values and the extent to which they are publicly advanced towards the process of policy formulation" (de Wilde, 2011, p. 560; see also Kertzer \& Zeitzoff, 2017). Most of the literature on politicization has so far focussed on the politicization of EU 
policy within the EU (De Bruycker, 2017; de Wilde \& Lord, 2016; Follesdal \& Hix, 2006; Hooghe \& Marks, 2009; Zürn, 2006). The most prominent explanation of politicization is the authority transfer hypothesis. Accordingly, politicization increases when the growing political authority of the EU is not perceived as legitimate (Zürn, 2004).

Recently, the EU's external trade policy has also received considerable attention by scholars, who have assessed the phenomenon of politicization in the context of trade negotiations with third parties. Most often, their focus is on politicization within the EU, instead of within third countries (De Bièvre, 2018; De Bièvre \& Poletti, 2017; De Ville \& Siles-Brügge, 2016; Gheyle \& De Ville, 2017; Siles-Brügge, 2017). Some scholars have applied the authority transfer hypothesis to better understand politicization of the recent Transatlantic Trade and Investment Partnership (TTIP) and the Comprehensive and Economic Trade Agreement (CETA) negotiations with the United States and Canada, respectively. In doing so, they conceptualise public contestation as a response to the inclusion of regulatory trade issues in negotiations with third parties (Laursen \& Roederer-Rynning, 2017). So-called deep integration issues include: "Food safety standards, trade facilitation measures and customs reform, intellectual property rights protection, government procurement liberalization, competition policies, and the liberalization of trade and investment in services as well as complementary domestic regulation" (Chauffour \& Kleimann, 2013, pp. 44-45).

Deep integration through FTAs thus implies that liberalization commitments do not only relate to traditional trade issues, such as cutting tariffs that take place at the border, but include complex behind-the-border issues that often touch upon domestic regulation. Most scholars suggest that-next to other factors-deep integration issues increase the politicization of FTAs because they potentially affect two of the three core dimensions of politicization: the expansion of actors (and audiences), and the salience of the issues at stake (de Wilde, Leupold, \& Schmidtke, 2016, p. 6; the third dimension is polarization).

This is, firstly, because the intrusion into regulatory practices that results from deep integration issues (De Bièvre \& Poletti, 2017, pp. 1511-1512) makes the mobilisation of a broader range of NSAs more likely. Young (2016, p. 364), for instance, claims that the breadth and depth of the TTIP has "raised the stakes for civic interest groups beyond those narrowly opposed to globalization." Taking the example of TTIP, its politicization is often presented as the result of value-based opposition from civil society organizations (CSOs), rather than from traditional economic interest groups (De Ville \& Siles-Brügge, 2016, p. 1496). For instance, public health non-governmental organizations or local authorities that have previously been much less active on trade agreements became involved in the TTIP process (De Ville \& Siles-Brügge, 2016, p. 1495; for an opposing view see Dür \& Lechner, 2015). Where a broader range of NSAs is in- volved in trade policy-making and complex and politically sensitive topics are at issue, politicization is likely to occur (Buonanno, 2017; Park, 2017).

Secondly, the complexity of trade agreements leads to considerable amounts of uncertainty, which in turn potentially affects the salience of the issues at stake. Regarding deep trade issues, uncertainty relates to the optimal depth of integration, required adjustment costs of policy implementation and, most importantly, the broader economic and social impact for society (Chauffour \& Kleimann, 2013, p. 52). As a result, NSAs have ample opportunities for strategic framings that potentially increase the salience of the issues they mobilise on. Siles-Brügge (2017, p. 466) claims that the broader and deeper agenda of trade agreements facilitates mobilisation because it allows for emotive framings that tend to have a high salience as compared to technical ones. The emotive framing of the proposed investorto-state dispute settlement mechanism as a "threat to democracy" was a potentially more threatening outcome to TTIP than simply the effects of cutting tariffs (Siles-Brügge, 2017). As Siles-Brügge notes (2017, p. 473), "opposition to ISDS can more easily be emotively communicated than other, more technical issues."

However, scholars also point at several intervening variables that affect the extent and timing, or even the absence, of politicization in the context of EU trade negotiations. Paying attention to these factors helps us to better understand why the inclusion of deep integration issues does not automatically trigger politicization. Firstly, the literature on politicization has generally found that pre-existing resources for mobilisation play a crucial role. Mobilisation resources depend on aspects such as "the number of organizations operating in a certain field, (preexisting) network linkages between groups, financial resources, or specific expertise" (Gheyle, 2016, pp. 8-9). More precisely, politicization is shaped by the existence, clout, and ability of networks of actors to engage in politicization (see De Bièvre, Garcia-Duran, Eliasson, \& Costa, 2020; Gheyle, 2016, pp. 8-9). For instance, De Bièvre (2018, p. 77) finds that large, wealthy NGOs in Germany were crucial driving factors behind the politicization of TTIP in the European context. Secondly, scholars generally claim that political opportunity structures affect the occurrence and level of politicization, in particular because they may encourage or discourage the participation of actors engaged in contentious politics. While political opportunity structures differ across policy fields, they-according to Cinalli and Giugni (2014, p. 90)generally include a degree of institutional access and participatory mechanisms. With regard to the realm of trade, this relates, for instance, to the institutional channels that NSAs can rely upon to access and participate in the process of trade policy-making. Thirdly, it has been noted that discursive opportunity structures influence the extent to which particular framings resonate broadly with a given audience, and thus may affect their salience (Koopmans \& Statham, 1999, p. 228). Other intermedi- 
ary variables discussed in the literature on the politicization of EU FTAs include (perceptions of) the bargaining power and economic size of the trading partner, which influence whether or not the EU's negotiation partner is perceived as a threat (De Bièvre \& Poletti, 2020).

What is missing from the literature, however, is a greater engagement with the external dimension of the politicization of EU trade policy-making. The EU's deep integration negotiating agenda potentially also affects politicization in its partner countries, which in turn holds the potential to delay or undermine reaching an agreement, or to affect the substance of the trade policies agreed upon. It remains unclear, however, whether and how the inclusion of deep integration in EU trade policies increases politicization across its partner countries.

This link is particularly questionable if we consider negotiations between the EU and partner countries in the developing world. The existing literature on the role of NSAs in trade policy-making in the developing world has shown that NSAs tend to face considerable financial, technical, and institutional capacity constraints that may limit their ability to effectively engage in the process of trade policy-making (Jones, 2013). This, in turn, is likely to affect politicization patterns because it may undermine mobilisation resources and political opportunity structures available to NSAs. There is, for instance, a mixed track record of lobbying efforts by NSAs such as African trade unions as to whether or not political opportunity structures facilitate African agency (Mohan \& Lampert, 2013, p. 109). Regarding the West African EPA negotiations, scholars find, for instance, that the opportunities of NSAs for participating in the negotiation process greatly shaped the influence (Del Felice, 2014; Trommer, 2014) or lack of influence (Montoute, 2016) they had, and that detachment between trade negotiators and domestic constituents affected negotiation dynamics (Weinhardt \& Moerland, 2018).

Methodologically, we make use of a qualitative case study approach. We focus on two cases-West Africa and the Caribbean in EPA negotiations with the EU-that consist of 'anomalies' in the sense that they do not seem to conform to the presumed link between the inclusion of deep integration issues and the pattern of politicization. Doing so helps us to re-assess the theoretical assumptions at stake, as well as to explore how capacity constraints may have shaped the conditions for politicization to occur. Both cases are comparable in the sense that the EU had initially offered identical agreements (that included deep integration issues) to both regions. However, we take into account that certain conditions for concluding an EPA were not identical for both regions: In contrast to the West African region, the vast majority of countries in the CARIFORUM had a strong incentive to conclude an agreement on trade in goods with the EU. Except for Haiti as a least developed country, all other countries faced the termination of preferential market access to the EU without the EPA. This does not, however, explain why the inclusion of deep integration issues re- mained largely uncontested because concluding merely a trade-in-goods agreement would have been sufficient to secure continued market access.

In the case studies, we assess whether the expectations of the literature hold, and what role intermediary variables played in shaping the different patterns of politicization. More precisely, we examine if and how: (1) limited mobilisation resources and (2) political opportunity structures have affected a presumed actor expansion in response to deep integration issues among NSAs during the EPA process; and (3) how discursive opportunity structures impacted NSAs' ability to frame deep integration issues to increase issue salience. Note that there is also the possibility that other aspects of the FTAs may have triggered politicization. We understand NSAs to comprise both CSOs and private sector actors. While West Africa and the Caribbean vary regarding the level of political accountability of policy-makers (Weinhardt \& Moerland, 2018, pp. 583, 586), we assume that sufficient political freedom existed for NSAs to participate in public debates given the predominance of democracies within the regions. Political activities can include hidden activities such as lobbying and representing interests (Cinalli \& Giugni, 2014, p. 85), or the communication of their opinions, interests, or values in public debates or protests with the aim to influence the policy process.

\section{Low Levels of Politicization in the Caribbean Region despite the Inclusion of Deep Integration Issues}

The CARIFORUM-EC EPA negotiations took place between April 2004 and December 2007 and were characterized by a rather fast process of negotiations, as compared to the other ACP regions. The negotiations were led by the Caribbean Regional Negotiation Machinery (CRNM), a body established in order to use the limited human and financial resources in the region in an effective way. Due to the looming termination of preferential market access to the EU without the EPA, CARIFORUM countries were under pressure to conclude at least a trade-in-goods agreement. The final agreement did, however, not only cover trade in goods, but included deep integration issues, such as services and investment, IP protection, e-commerce, public procurement, environment, and competition rules. This contrasts with the Economic Commission for West African States (ECOWAS) region, where only an agreement on trade in goods could be reached. The case study on the EPA negotiations between the EU and the Caribbean region relies on evidence specific to IP protection, one of the important deep integration issues covered.

The inclusion of deep integration issues in the CARIFORUM-EC EPA did not lead to high levels of politicization, as would have been expected. The EPA received very limited attention from the media and the wider public during the negotiations. There were relatively small and general anti-EPA demonstrations organized in CARIFORUM countries in 2004 (Girvan, 2010, p. 103), 
but most of the controversy that ensued around the EPA took place just before the conclusion of the agreement in November/December 2007 and before the ministerial signature in October 2008. However, according to Girvan (2010, p. 107), "the EPA renegotiation campaign of regional civil society and regional labour unions did not attract the level of mass support capable of putting real pressure on the governments." They did not focus on deep integration areas either, nor on other specific issues. Politicization did increase after the conclusion of the EPA, but in particular around the rather low political accountability of the CRNM negotiating team, leading to the abolition of that body.

We argue that limited mobilisation resources and weak political opportunity structures withheld NSAs from engaging in politicization on deep integration issues in a meaningful way.

\subsection{Actor Expansion I: Limited Resources Impede NSA Mobilisation Regarding Deep Integration Issues}

Already in the early stages of the negotiations, technical negotiators lacked meaningful input as to the preferences of national and regional constituents in deep integration areas like IP (M. Spence, interview, April 7, 2010). One of the most important reasons for that was an apparent lack of a deeper understanding by NSAs. The private sector and CSOs in the region did not perceive IP (or other deep integration areas) as a priority yet. With a focus on broader and less technical topics, like sustainable development and trade liberalization, their knowledge on deep integration areas remained low (J. Spence, interview, April 7, 2010; S. Munro-Knight, interview, May 13, 2010; O. Chedda, interview, April 12, 2010). As a consequence, only a few CSOs and private sector organizations formulated a position on IP issues regulated through the EPA; only 4 out of the 12 NSAs interviewed had specific interests in various fields of IP protection (Moerland, 2013, p. 531). This shows that while deep integration issues in principle affect more actors than traditional areas, they were not in a position to formulate preferences and engage in discussions due to low levels of understanding.

Limited financial resources also made it difficult to obtain the relevant knowledge by themselves. Without such capacity, CSOs cannot conduct research to make informed interventions and to build awareness (Montoute, 2016, p. 316). For the area of IP, Caribbean CSOs, such as Caribbean Policy Development Centre (CPDC), relied on studies carried out by international CSOs, such as the South Centre and the Third World Network (J. Spence, interview, April 7, 2010).

\subsection{Actor Expansion II: Political Structures Impede Mobilisation on Deep Integration Issues}

In addition to low levels of understanding and resources, CSOs faced several problems with regard to the discussion of deep integration issues in regional and na- tional activities organized by CRNM. Very few of these consultation meetings addressed IP protection in depth (Moerland, 2013, p. 539). In fact, several stakeholders only learned about the IP chapter before the signing of the EPA (B. Pereira, interview, April 6, 2010; N. Girvan, interview, April 22, 2010). In addition, regional and national consultations with relevant stakeholders were geared towards involving business and industry representatives rather than CSOs. Only a few events could be identified that addressed civil society actors (Moerland, 2013, p. 540). This reveals a certain bias in the organization of consultations by CRNM towards private sector interests. Also across other trade areas, ACP-EU economic and social interest groups in the Caribbean region regretted the insufficient information available to NSAs on the negotiations, the inadequate consultations, and the limited capacity of economic and social interest groups to participate in the process (European Economic and Social Committee, 2007, para. 29).

At the same time, CRNM felt that CSOs did not respond to deep integration issues addressed during the negotiations because they lacked organizational capacity (CRNM, 2008). Their input was mainly directed towards development issues and was often perceived as not being constructive (J. Lodge, interview, March 3, 2010). In fact, technical negotiators' expertise was far superior as compared to national and regional state and NSAs, making a conversation on par almost impossible (Moerland, 2013, p. 579). The technical nature of many deep integration issues, therefore, constituted an impediment for NSAs in the Caribbean to formulate policy positions. Montoute $(2016$, p. 316) arrives at a similar conclusion for other negotiating areas as well: Due to a lack of capacity and lack of confidence that their views would matter, CSO representation was very low. With CRNM negotiators enjoying a rather large negotiating autonomy (Girvan, 2009, p. 14), they could rely predominantly on their own expertise and values to formulate CARIFORUM's negotiating position. In this case, the delegation of power to CRNM enabled deep integration issues such as competition, public procurement, e-commerce, environment, and social aspects to be included in the EPA without much mobilisation, as would have been expected. This means political preferences of state representatives rather than the positions of NSAs were instrumental for the inclusion of deep integration issues.

\subsection{Issue Salience: Technicality of Deep Integration Issues Hinders Effective Framing}

Deep integration issues, such as IP rules, often contain a high level of technical detail and complexity, which presents a barrier for NSAs to create issue salience. Caribbean NSAs faced the challenge of: (1) understanding the technical and complex provisions; and (2) communicating their views about them to the public. This implies that few discursive opportunity structures existed to politicise the inclusion of deep trade issues. 
As a senior programme officer of CPDC puts it: its officers felt they lacked the level of expertise to speak comfortably on behalf of society on IP issues (S. Munro-Knight, interview, May 13, 2010). Bishop, Heron, and Payne (2013, p. 83) conclude that one of the major criticisms of the Caribbean EPA was the highly technocratic way in which negotiations were handled. Such technical and complex topics impacted the possibility for Caribbean NSAs to engage in strategic (emotive) framing. We find that too much complexity can undermine a conducive framing that highlights the uncertainties involved and from which CSO actors could have benefitted in their campaigns. As Girvan (2010, p. 106) noted, "technical arguments by themselves were insufficient to sway the governments. The issues were too complex to be easily understood." This leads us to conclude that NSAs in the Caribbean did not choose complex deep integration issues as themes of discussion.

Instead of framing the uncertain impact of deep integration issues in their communication, many Caribbean NSAs chose broader social and political issues for targeting the general public and society. As Montoute (2016, p. 315) finds, CSOs considered general issues instrumental in driving the process. Both CSOs and private sector organizations in the region focussed on sustainable development, the neo-liberal paradigm present in the negotiations and importantly market access (J. Spence, interview, April 7, 2010; S. Munro-Knight, interview, May 13, 2010; O. Chedda, interview, April 12, 2010). When NSAs formed a position regarding deep integration issues, it was to oppose their inclusion into the EPA. For example, CPDC argued that IP commitments beyond the Agreement for Trade-Related Aspects of Intellectual Property Rights should be avoided (J. Munro-Knight, interview, May 13, 2010). However, this did not become an emotive frame that drew public attention, but rather served as a rational argument based on costbenefit calculations.

\section{Politicization in the West African Region Linked to the Traditional Trade in Goods Agenda}

The EPA negotiations between the EU and the West African region-represented by the ECOWAS-began in 2003 and lasted until 2014. Like the Caribbean case, the EU intended to cover deep integration issues such as the liberalization of trade in services and the so-called Singapore issues (competition policy, trade facilitation, government procurement and investment) in the EPA. However, in contrast to the Caribbean case, the final agreement was limited to the traditional realm of trade in goods and excluded deep integration issues. These issues were only covered by a so-called rendezvous-clause that stipulated that negotiations on these issues will be considered in the future.

In contrast to the Caribbean case, a number of NSAs engaged in relatively high levels of politicization of the EPA (cf. Del Felice, 2014, p. 153; Heron \& Murray-Evans,
2017, pp. 355-357; Langan \& Price, 2015; Trommer, 2014). Politicization was particularly high in the year before the originally envisaged negotiation deadline-end of December of 2007-but the 'Stop EPA!' campaign that united key NSAs in the region remained active until 2009 (Trommer, 2014). The political activities of NSAs included both attempts to influence political decision-makers at the national and regional level in consultation processes, as well as public opinion through publications on the EPA process and offline and online campaigns (Onyekwena, Weylandt, \& Akanonu, 2017, p. 4).

In contrast to the expectation in the existing literature, we find that politicization was not linked to the proposal to include deep integration issues into the EU-ECOWAS EPA. This inclusion did not lead to actor expansion because technical, financial, and institutional capacity constraints prevented private sector actors, in particular, from engaging with the negotiation agenda on deep integration issues. Conversely, politicization was driven by a number of trade-oriented CSOs that-in contrast to private sector actors-were able to draw on preexisting expertise and networks (mobilisation resources) and made active use of the inclusion in the regional negotiation team of ECOWAS (political opportunity structures). Their political activities, however, focussed on the broad risks they associated with the neo-liberal underpinnings of the traditional trade in goods aspects that were included in the final agreements. Lastly, we find that the inclusion of deep trade issues does not increase the opportunities for emotive framings if trade in goods remains a political priority in EU negotiating partners, and awareness of deep trade issues remains rather low (discursive opportunity structures).

\subsection{Actor Expansion I: Uneven Mobilisation Resources Prevent Actor Expansion in Response to Deep Integration}

The initial EU proposal included deep integration issues in the EPAs. The inclusion of these issues in the negotiation process was reflected in the set-up of the technical negotiating groups in West Africa, which included working groups on trade-related issues (competition policy, investment, and intellectual rights) and on services (IDS \& CARIS, 2010). While these issues were eventually excluded, the EU draft negotiating text for the ECOWAS EPA still contained comprehensive clauses on these deep integration issues (ODI \& ECDPM, 2008). Yet, we find that the initial inclusion of deep integration issues did not lead to an expansion of actors involved in mobilisation. Those NSAs that did engage in politicization responded to traditional trade topics only. This pattern becomes understandable if we take the uneven spread and oftentimes low levels of pre-existing mobilisation resources into account that prevented the inclusion of a broader range of NSAs.

Politicization in the West Africa region was driven by a group of trade-focussed civil society actors that 
launched the West African Civil Society Platform on the Cotonou Agreement (POSCAO), a coalition that comprised 14 organizations from 12 countries (Wern $\varnothing, 2013$ ) to coordinate their political activities on EPA negotiations (Trommer, 2014). While the platform was critical of the inclusion of deep integration issues on the negotiation agenda (Del Felice, 2014, p. 161), their campaign mainly related to traditional trade in goods issues and the debate concerning financial support (cf. Trommer, 2014; Del Felice, 2014). POSCAO benefitted from preexisting structures, including the Africa Trade Network, and joined broader networks, such as the African Social Forum (Del Felice, 2014). Thus, this group of CSOs that was comparatively well endowed in terms of human and financial capacities was instrumental for driving the politicization process in the West African region.

Actor expansion in response to deep integration issues did not take place, given that even the majority of private sector actors lacked the resources necessary to engage in politicization (cf. Fofana, 2007, p. 4). In general, a study by the European Parliament found that most business actors in West Africa "have little or no information and do not have the capacity to follow closely the EPA negotiations" (Kwa, Lunenborg, \& Musonge, 2014, p. 33). Capacity constraints were particularly acute regarding the deep integration agenda. For instance, in Nigeria-a key economy in West Africa-the small size of most service firms (less than 10 employees) and their limited capital base meant that they had "little if any coordinated representation" (NANTS \& ILEAP, 2009, p. 10). As a result, the few mobilisation efforts by business actors that did occur did not focus on contentious deep integration issues such as competition policy and investment (Rampa, 2007, p. 28) but resulted rather from concerns about losing preferential market access to the EU (OFSE, 2018, p. 86) or tariff cuts on the West African side (IDS \& CARIS, 2010, p. 142).

\subsection{Actor Expansion II: Political Opportunity Structures Facilitate Access of NSAs to the Regional Negotiation Level}

Participatory channels for NSAs existed in EPA negotiations, yet they were not comprehensive enough to contribute to a broadening of the basis of NSAs involved in politicization in a significant way. This undermined the link between the inclusion of deep integration issues and politicization because most NSAs lacked adequate political channels to make their positions heard (i.e., the service sector had weak links to the regional negotiation level, Kwa et al., 2014, p. 33).

While the majority of NSAs had difficulties in directly influencing the political level of decision-making in the EPA process, a selected number of NSAs had very good access. There was a unique negotiating set-up that differed from the Caribbean case: ECOWAS included a civil society representative and a private sector representative from the agricultural sector on the regional nego- tiating team (interview with EU official, February 19, 2010, Brussels; Trommer, 2014, pp. 11-14), resulting in a close and allegedly "very good relationship" with these NSAs (phone interview with former ECOWAS official, November 1, 2011). While both representatives did not hold co-decision powers, they were able to advice decision-makers, provide technical input or defend the ECOWAS position (Trommer, 2014, p. 14). The inclusion on the negotiation team facilitated their political engagement-including their campaign against EPAsbecause of better access to information and decisionmakers. In particular, Cheick Tidiane Dieye, the civil society representative at the ECOWAS level, who also formed part of POSCAO, was very vocal in publicly criticising the EU proposals on EPAs (Weinhardt, 2019, p. 138). On the European side, some negotiators even perceived him as acting as if he was a "fully fledged negotiator from ECOWAS" and at times adding "an obstructive element which can turn the negotiations" (interview with EU official, February 15, 2010, Brussels). While he contributed to the politicization of the negotiating process, other civil society actors at times did not feel represented well by him, arguing that it is not enough to "choose one person for a whole region" (phone interview with civil society actor from Ivory Coast, October 17, 2011; authors' translation from French).

This negotiation set-up nonetheless represents an important difference with the Caribbean case, where the CRNM consisted of political and technical negotiators only, and where relations with NSAs were weak. This, together with the differences regarding pre-existing knowledge and resources with at least one group of African NSAs, help us to understand why politicization was higher in the West African as compared to the Caribbean case, even if political opportunity structures were not comprehensive enough to facilitate actor expansion.

\subsection{Issue Salience: Framing as 'Anti-Developmental' Liberalisation Instead of 'Dangerous' Deep Trade Integration}

Similar to the Caribbean case, despite the inclusion of deep integration issues on the negotiation agenda, these technical issues did not play a role in the way civil society actors framed their campaign on EPAs. This was partly the case because at the political level, negotiations made little progress on these issues. Many government actors lacked the capacity and willingness to initiate negotiations on these far-reaching deep integration issues. As a result, the technical-thematic groups that dealt with IP and services struggled to define the exact scope of their work in the run-up to the originally envisaged negotiating deadline of December 2007 (African Trade Policy Centre, 2007 , p. 47). To the contrary, making sure that EPAs offer better market access in terms of trade in goods remained a political priority for ECOWAS negotiators and national governments. This in turn shaped the focus of the 'Stop EPA' campaign of civil society actors. Here, 
the different economic preferences between the West African and Caribbean region also mattered in the sense that most ECOWAS member states were not under pressure to reach an agreement to secure continued preferential market access to the EU.

As a result, in their campaign, civil society actors made use of the uncertainty related to traditional market opening towards the EU, i.e., the lowering of tariffs on EU imports, to strategically frame the EPAs as "fundamentally anti-developmental" (Africa Trade Network, 2006; see also Coomson, 2007), a threat to local producers, or even as part of a neo-colonial agenda of the EU. The absence of studies on the effects of EPAs created this "space for suspicion" (IDS \& CARIS, 2010, p. 136). Civil society actors focussed their framing on "the inequalities and unfairness of the EPA [in order] to reject it completely" (African Trade Policy Centre, 2007, p. 49) and did not target specific deep integration issues.

These findings resonate with the existing literature in the sense that NSAs made strategic use of uncertainties about the potential effects of the proposed FTA to push for an emotive framing that resonated broadly and avoided the danger of technification. In contrast to existing views, however, such uncertainties were not related to the deep integration issues on the agenda given that political priorities lay on traditional trade liberalization. Moreover, lower awareness and the lack of concrete negotiations on these issues made it more difficult to use a framing that resonated widely (discursive opportunity structures).

\section{Conclusion}

Many authors that assess politicization of recent EU trade negotiations such as TTIP or CETA, have come to the conclusion that the more negotiations focus on deep integration issues, the higher the potential for politicization. This is because the comprehensive nature of nontraditional trade issues allows domestic constituents to mobilise broader coalitions that go beyond traditional economic actors. The uncertainties associated with complex behind-the-border regulatory reforms open up opportunities for (emotive) strategic framings that resonate widely. Yet, we find that this assumed link between deep integration in FTAs and politicization does not necessarily hold true in developing partner countries of the EU. We find that in the case of the EPAs between the EU and West Africa and the Caribbean region, respectively, patterns of politicization in both partner countries did not occur because of the inclusion of deep integration issues in the negotiations, but depend more on pre-existing mobilisation resources, political and discursive opportunity structures.

In the Caribbean, low mobilisation resources, limited opportunities for participating and interacting with the negotiations at the regional level, and the difficulty to frame technical and complex issues effectively undermined an engagement of NSAs with deep integration is- sues. In particular, lack of information and expertise on deep integration issues such as IP meant that NSAs were not in a position to formulate their preferences to the public or in consultations. Where NSAs were engaged in the EPA negotiations, it was in relation to less technical aspects like sustainable development or market access, which NSAs felt more confident about and which they could use for salient framing. Even though deep integration issues presented many uncertainties, they were perceived as too complex and technical to be easily understood by the public.

In West Africa, the higher-level politicization was mainly driven by pre-existing mobilisation resources and political opportunity structures for a group of NSAs: A selected number of civil society actors was able to rely on pre-existing expertise and trade-related networks, and effectively engaged in politicization. Their efforts were magnified by the opportunity to send a representative to the regional negotiating team of ECOWAS. These political activities, however, focussed on more traditional trade liberalization topics rather than deep integration aspects of the agreement. Overall, we thus did not find actor expansion as a result of the inclusion of deep integration issues on the negotiation agenda, also because the majority of NSAs did not have the means to mobilise. Issue salience did not increase either, as NSAs opted for a general anti-developmental framing that addressed uncertainties about the developmental effects of traditional market opening towards the EU, arguably because traditional trade aspects were far more significant to most West African economies than deep integration issues.

These findings suggest that it is difficult to generalise patterns of politicization linked to deep integration issues. At a general level, we show that in both cases, patterns of politicization do not follow the assumptions of the authority transfer hypothesis. Instead, our findings support earlier research that has indicated that intermediary variables play an important role in shaping politicization (de Wilde et al., 2016). Our case studies show that insufficient or missing mobilisation resources, political, and discursive opportunity structures counteract the expected actor expansion and increased issue salience in response to the inclusion of deep integration issues. Our case studies show that pre-existing knowledge, financial resources, and network structures are crucial for actor mobilisation: In the Caribbean, these were largely absent, while in West Africa, it was primarily a relatively well-endowed network of trade-focussed civil society actors that engaged in politicization. Regarding issue salience, we find that the oftentimes low capacity to engage with complex deep integration issues also implies that emotive framings tend to be used for the politicization of broad dangers associated with neo-liberal free trade policies.

More generally, our findings indicate that if the EU negotiates deep integration issues with developing country partners, the level of awareness among NSAs will vary greatly and will oftentimes be low. If NSAs engage in 
politicization, they are thus less likely to focus the limited resources they have on complex deep integration issues. This also implies that support or opposition to including deep integration issues may primarily depend on the political preferences of state representatives, rather than the positions of NSAs. We find that the West African resistance to or the Caribbean acceptance of the deep integration issues proposed by the EU was not-or not only-related to politicization efforts by NSAs. Instead, it also reflected the divergent preferences and levels of autonomy of regional negotiators. CRNM negotiators were relatively autonomous and strongly in favour of including the Singapore issues and liberalization of services as part of the EPA deal. Conversely, ECOWAS negotiators faced higher levels of politicization from NSAs and were also more dependant upon ECOWAS member states that tended not to buy into the EPA agenda.

\section{Acknowledgments}

For their critical comments and helpful suggestions on earlier drafts of this article we thank Iskander De Bruycker, the editors of this thematic issue, as well as three anonymous reviewers. Please note that both authors contributed equally to the study.

\section{Conflict of Interests}

The authors declare no conflict of interests.

\section{References}

Introduction to this Thematic Issue

Africa Trade Network. (2006). Forward with the struggle to stop the EPAs: Declaration of the 9th annual meeting of the Africa trade network. Accra: Africa Trade Network. Retrieved from https://www2.weedonline.org/uploads/atn_declaration_2007.pdf

African Trade Policy Centre. (2007). EPA negotiations: African countries continental review (Work in Progess No. 64. February 2007). Addis Ababa: Economic Commission for Africa.

Bishop, M., Heron, T., \& Payne, A. (2013). Caribbean development alternatives and the CARIFORUMEuropean Union economic partnership agreement. Journal of International Relations and Development, 16(1), 82-110.

Buonanno, L. A. (2017). The new trade deals and the mobilisation of civil society organizations: Comparing EU and US responses. Journal of European Integration, 39(7), 795-809.

Caribbean Regional Negotiation Machinery. (2008, March 27). CRNM EPA reflections. RNM Update 0801.

Chauffour, J.-P., \& Kleimann, D. (2013). The challenge of implementing preferential trade agreements in developing countries: Lessons for rule design. In D. Kleimann (Ed.), EU preferential trade agreements:
Commerce, foreign policy and development aspects (pp. 43-55). Florence: European University Institute.

Cinalli, M., \& Giugni, M. (2014). The impact of political opportunity structures on the politicization of civil society organizations in the field of unemployment and precarity. In S. Baglioni \& M. Giugni (Eds), Civil society organizations, unemployment, and precarity in Europe (pp. 85-106). London: Palgrave Macmillan.

Coomson, J. (2007). Govts should get involved in EPAs negotiations. Ghanaweb. Retrieved from https://www.ghanaweb.com/GhanaHomePage/ business/Govts-should-get-involved-in-EPAsnegotiations-130579

De Bièvre, D. (2018). The paradox of weakness in European trade policy: Contestation and resilience in CETA and TTIP negotiations. The International Spectator, 53(3), 70-85.

De Bièvre, D., Garcia-Duran, P., Eliasson, L. J., \& Costa, O. (2020). Editorial: Politicization of EU trade policy across time and space. Politics and Governance, 8(1), 239-242.

De Bièvre, D., \& Poletti, A. (2017). Why the Transatlantic Trade and Investment Partnership is not (so) new, and why it is also not (so) bad. Journal of European Public Policy, 24(10), 1506-1521.

De Bièvre, D., \& Poletti, A. (2020). Towards explaining varying degrees of politicization of EU trade agreement negotiations. Politics and Governance, 8(1), 243-253.

De Bruycker, I. (2017). Politicization and the public interest: When do the elites in Brussels address public interests in EU policy debates? European Union Politics, 18(4), 603-619.

De Ville, F., \& Siles-Brügge, G. (2016). Why TTIP is a gamechanger and its critics have a point. Journal of European Public Policy, 24(10), 1491-1505.

de Wilde, P. (2011). No polity for old politics? A framework for analyzing the politicization of European integration. Journal of European Integration, 33(5), 559-575.

de Wilde, P., Leupold, A., \& Schmidtke, H. (2016). Introduction: The differentiated politicization of European governance. West European Politics, 39(1), 3-22.

de Wilde, P., \& Lord, C. (2016). Assessing actually-existing trajectories of EU politicization. West European Politics, 39(1), 145-163.

Del Felice, C. (2014). Power in discursive practices: The case of the STOP EPAs campaign. European Journal of International Relations, 20(1), 145-167.

Dür, A., \& Lechner, L. (2015). Business interests and the transatlantic trade and investment partnership. In T. Novotná, M. Telò, J. F. Morin, \& M. F. Ponjaert (Eds.), Politics of transatlantic trade negotiations: TTIP in a globalized world (pp. 69-79). Abington: Routledge.

Eliasson, L. J., \& García-Duran, P. (2017). Why TTIP is an unprecedented geopolitical game-changer, but not a Polanyian moment. Journal of European Public Policy, 24(10), 1522-1533. 
European Commission. (2006). Global Europe: Competing in the world. Brussels: European Commission.

European Economic and Social Committee. (2007). Final declaration. Presented at the 9th Regional Seminar of ACP-EU Economic and Social Interest Groups, Barbados, Caribbean.

Fofana, A. (2007). Chairman's opening remarks. Presented at National Seminar on the Economic Partnership Agreement (EPA): Positioning Sierra Leone, Location. Retrieved from http://www.bsl.gov.sl/pdf/ Seminar\%20on\%20Economic\%20Partnership.pdf

Follesdal, A., \& Hix, S. (2006). Why there is a democratic deficit in the EU: A response to Majone and Moravcsik. Journal of Common Market Studies, 44(3), 533-562.

Gheyle, N. (2016). Adding fuel to the flames: How TTIP reinvigorated the politicization of trade. Paper presented at the Governance and Integration through Free Trade Agreements (GIFTA), Brussels, Belgium.

Gheyle, N., \& De Ville, F. (2017). How much is enough? Explaining the continuous transparency conflict in TTIP. Politics and Governance, 5(3), 16-28.

Girvan, N. (2009). The Caribbean EPA affair: Lessons for the progressive movement. Paper presented at the Remembering the Future: The Legacies of Radical Politics in the Caribbean, Pittsburgh, USA.

Girvan, N. (2010). Technification, sweetification, treatyfication. Interventions, 12(1), 100-111.

Heron, T., \& Murray-Evans, P. (2017). Limits to market power: Strategic discourse and institutional path dependence in the European Union-African, Caribbean and Pacific economic partnership agreements. European Journal of International Relations, 23(2), 341-364.

Hooghe, L., \& Marks, G. (2009). A postfunctionalist theory of European integration: From permissive consensus to constraining dissensus. British Journal of Political Science, 39(1), 1-23.

IDS, \& CARIS. (2010). EPA review: Annex documents. Sussex: Institute of Development Studies \& Centre for the Analysis of Regional Integration at Sussex.

Jones, E. (2013). Negotiating against the odds: A guide for trade negotiators from developing countries. Basingstoke: Palgrave Macmillan.

Kertzer, J. D., \& Zeitzoff, T. (2017). A bottom-up theory of public opinion about foreign policy. American Journal of Political Science, 61(3), 543-558.

Koopmans, R., \& Statham, P. (1999). Ethnic and civic conceptions of nationhood and the differential success of the extreme right in Germany and Italy. In M. Giugni, D. McAdam, \& C. Tilly (Eds.), How social movements matter (pp. 225-252). Minneapolis, MN: University of Minnesota Press.

Kwa, A., Lunenborg, P., \& Musonge, W. (2014). African, Caribbean and Pacific (ACP) countries' position on Economic Partnership Agreements (EPAs) (Study EXPO/B/DEVE/2013/30). Brussels: European Parliament.
Langan, M., \& Price, S. (2015). Extraversion and the West African EPA development programme: Realising the development dimension of ACP-EU trade? The Journal of Modern African Studies, 53(3), 263-287.

Laursen, F., \& Roederer-Rynning, C. (2017). Introduction: The new EU FTAs as contentious market regulation. Journal of European Integration, 39(7), 763-779.

Moerland, A. (2013). Why Jamaica wants to protect champagne: Intellectual property protection in EU bilateral trade agreements. Oisterwijk: Wolf Legal Publishers.

Mohan, G., \& Lampert, B. (2013). Negotiating China: Reinserting African agency into China-Africa relations. African Affairs, 112(446), 92-110.

Montoute, A. D. (2016). Deliberate or emancipate? Civil society participation in trade policy: The case of the CARIFORUM-EU EPA. VOLUNTAS: International Journal of Voluntary and Nonprofit Organizations, 27(1), 299-321.

NANTS, \& ILEAP. (2009). Advancing services sector development and reforms in Nigeria: Final report of the national stakeholder workshop. Abuja: National Association of Nigerian Traders and International Lawyers and Economists Against Poverty.

ODI, \& ECDPM. (2008). The new EPAs: Comparative analysis of their content and the challenges for 2008. London and Maastricht: Overseas Development Institute and European Centre for Development Policy Management.

OFSE. (2018). The economic and social effects of the Economic Partnership Agreements on selected African countries (Research Report No. 7/2018). Vienna: Austrian Foundation for Development Research (OFSE).

Onyekwena, C., Weylandt, M., \& Akanonu, P. (2017). The role of civil society organizations in improving national policy prepared for the African policy circle: $A$ case study of Nigeria's trade negotiations in the EUECOWAS economic partnership agreement (African Policy Circle Position Paper). Berlin: African Policy Circle. Retrieved from https://africanpolicycircle. net/wp-content/uploads/2017/05/apc_csonational-policy.pdf

Park, S. (2017). The new politics of trade negotiations: The case of the EU-Korea FTA. Journal of European Integration, 39(7), 827-841.

Rampa, F. (2007). Implementation of article 37 (4) of the Cotonou Agreement: Provision of technical support to assist the Pacific ACP region in the review of EPA negotiations. (Draft Interim Report submitted to the Pacific Islands Forum Secretariat). Maastricht: European Centre for Development Policy Management.

Siles-Brügge, G. (2017). Transatlantic investor protection as a threat to democracy: The potency and limits of an emotive frame. Cambridge Review of International Affairs, 30(5/6), 464-488.

Trommer, S. (2014). Transformations in trade politics: Participatory trade politics in West Africa. Abingdon: Routledge. 
Weinhardt, C. (2019). Negotiating trade in uncertain worlds: Misperception and contestation in EU-West Africa relations. Abingdon: Routledge.

Weinhardt, C., \& Moerland, A. (2018). (Mis)perceptions in two- and three-level games: Detachment in economic partnership agreement negotiations. Journal of Common Market Studies, 56(3), 576-593.

Wern $\varnothing$, H. L. (2013). Nothing but negotiations: Explaining the lack of agreement between the European Union and West Africa in the negotiations for an Economic Partnership Agreement (Unpublished Master's Thesis). University of Oslo, Oslo, Norway.

Young, A. R. (2016). Not your parents' trade politics: The
Transatlantic Trade and Investment Partnership negotiations. Review of International Political Economy, 23(3), 345-378.

Young, A. R. (2017). The new politics of trade: Lessons from TTIP. New York, NY: Agenda Publishing.

Young, A. R., \& Peterson, J. (2006). The EU and the new trade politics. Journal of European Public Policy, 13(6), 795-814.

Zürn, M. (2004). Global governance and legitimacy problems. Government and Opposition, 39(2), 260-287.

Zürn, M. (2006). Zur Politisierung der Europäischen Union [On the politisation of the European Union]. Politische Vierteljahresschrift, 47(2), 242-251.

\section{About the Authors}

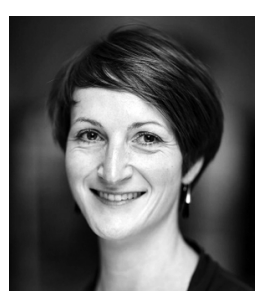

Anke Moerland is Assistant Professor of Intellectual Property Law at Maastricht University. Her research relates to the interface of intellectual property law and political science, with a focus on governance aspects of intellectual property regulation in international trade negotiations. Since 2018, she holds a Visiting Professorship in Intellectual Property Law, Governance and Art at the School of Law, Centre for Commercial Law Studies of Queen Mary University of London. ORCID: http://orcid.org/0000-0001-6902-9774

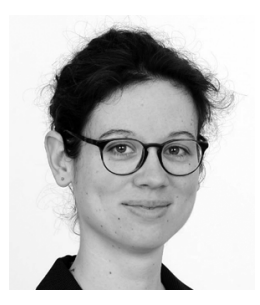

Clara Weinhardt is an Assistant Professor in International Relations at Maastricht University and a Non-Resident Fellow at the Global Public Policy Institute (GPPi) in Berlin. Her research focuses on global governance and international negotiations, with a focus on North-South relations in trade. ORCID: http://orcid.org/0000-0003-1830-1189 